\title{
Confluence
}

\section{Asian cultural contributions to ailan pasin ${ }^{1}$}

\author{
Anna Shnukal
}

\section{Introduction}

Ailan pasin ('island custom') is a potent symbol of pan-Torres Strait Islander identity; it is also a cultural hybrid. Its core consists of a cluster of 'traditional' Melanesian cultural elements filtered through 19th-century Pacific Islander Christian sensibility and practice, with accretions from Europe and Asia. That ailan pasin is not restricted entirely to pre-contact custom is evident from the inclusion of two symbolic unifiers brought by European-influenced Pacific Islanders during the last half of the 19th century: Christianity and Torres Strait Creole, a nativised variety of Pacific Pidgin English, which has become the regional lingua franca. The other significant, though often overlooked, contribution made by Asian immigrants is the subject of this chapter. ${ }^{2}$

The preconditions for extensive cultural interchange with Asians, Pacific Islanders and Europeans existed in Torres Strait long before contact. The region was a locus of west-east and north-south migration and trade and the island economies were underpinned by widespread exchange complexes, maintained by interrelationships with neighbours based on shifting alliances, warfare and intermarriage. Inter-island and coastal trade provided essential objects of material culture - canoes, vegetable food, ochre, cassowary feathers, stone for the gabagaba 'club', pearl shell for the dibidi 'breast ornament' — as well as less tangible elements, such as innovative technology, myth and cosmology. ${ }^{3}$ Traditional 
Islanders, like their contemporary descendants, were pragmatic and eager to adopt, adapt and elaborate cultural elements generated elsewhere for sustenance, performance and display. Moreover, the island peoples of Torres Strait, Asia and the Pacific shared social and cultural affinities, which predisposed them to cultural exchange. The development of bonds between the Torres Strait Islanders and the Chinese, Filipino, 'Malay', Japanese and Sri Lankan sojourners and immigrants provided fertile new areas for cultural crosspollination, the results of which can be observed in contemporary Torres Strait religion, food, cooking practices, plants, gardening techniques, clothing, architecture, household implements and cooking utensils, mortuary rites, music and dance, as well as vocabulary borrowed into the Torres Strait languages from Malay, Japanese, Tagalog and Chinese. Some early borrowings left little trace and are dealt with only briefly here. Others endured and became 'nativised', i.e., were integrated into pan-Islander custom, changed to some degree to conform to existing local custom and generally recognised as part of contemporary ailan pasin.

I note in passing that, in addition to the material and ideological elements that were incorporated into ailan pasin, early Asian immigrants brought significant changes to the created environment of the islands of Torres Strait: the destruction of wangai stands to fuel the ships and trepang smokehouses; the cutting down of mangroves as fuel and timber; the introduction to outer island gardens and plantations of tropical plants native to their islands of origin (most notably sisal hemp, known in the strait as 'Manila rope'); the digging of wells; the planting of market gardens on Thursday, Prince of Wales and Hammond Islands with Chinese cabbage, lettuce, lombok, silver beet, string and butter beans, watermelon and sugar cane; the building of graves and headstones for deceased countrymen on Thursday Island and elsewhere; the erection of dwellings and religious buildings in Malaytown and Yokohama on Thursday Island; the building of galvanised iron housing, outbuildings and tramways on pearling stations scattered around the strait; the construction by the Filipinos of the Catholic church, hospital and school on Thursday Island and the various buildings of Hammond Island Roman Catholic Mission.

\section{The Structural Context of Cultural Borrowing}

Linguists have long observed that a genetic relationship between languages facilitates lexical (and syntactic) borrowing, whereas unrelated languages are less likely to borrow one from another: that is, other things being equal, the more fundamentally similar the languages, the more rapid, thorough and extensive the linguistic borrowing when speakers are in contact. If this abstract principle can be extended to the cultural sphere, then Torres Strait Islanders might be 
expected to borrow more readily from cultures that more closely approximate their own than from 'unrelated' cultures (leaving aside the vexed question of how we might measure 'cultural difference' and 'degree of borrowing'). ${ }^{4}$

Given the socio-cultural affinities among the Indigenous communities of the wider region (noted in the Introduction), their similar maritime traditions and their shared working circumstances as non-White marine industry employees in remote colonial outposts of European empires, it is not surprising that friendships, alliances and family links were rapidly established. It was those links that provided the context for the liberal exchange of objects, practices and ideas between Asian and Torres Strait communities.

\section{Asian Cultural Borrowings into Contemporary Ailan Pasin}

The test for true incorporation of cultural borrowings into contemporary ailan pasin is their 'nativisation' and widespread distribution. The following originally Asian items have been modified in form and context of use through their appropriation by Islanders into Torres Strait custom. A review of the data suggests that most nativised borrowings fall into four cultural domains: food (ingredients, condiments, recipes, preparation and cooking methods, utensils); mortuary rites; the lexicon of the local languages; and music/dance.

Food: ingredients, condiments, recipes, preparation and cooking methods, utensils

Each Asian ethnic group sought to maintain its traditional diet as far as possible: the Chinese market gardeners on Thursday Island and neighbouring islands grew Asian green vegetables, including cabbage, lombok, lettuces and beans, and Chinese shopkeepers sold all manner of tinned Chinese delicacies in their shops: bamboo shoots, mushrooms, dried prawns, prawn paste (ha-ma) and long soup. The Filipino, Juan Francisco Garcia, planted more than 200 coconut trees on several islands, before settling permanently on Auridh (Skull Island), where he harvested the coconuts to make tuba, his Torres Strait Islander wife using the fermented drink as a rising agent when making bread. ${ }^{5}$ Green ginger root, garlic, lemon grass, chillies, cloves and cinnamon bark, curry powder and soy sauce were introduced; there was sufficient local demand for Haruyoshi Yamashita to establish a successful soy-sauce factory on Thursday Island. ${ }^{6}$ According to Gwen Clark Moloney, born in 1918 of European-SamoanFilipino-Chinese descent and raised on Thursday Island,

there were Japanese shops, boarding houses, drapery stores, where you could buy silks and Japanese novelties, souvenirs, carved trunks and Japanese food. In the morning you could buy tofu floating in water in green-painted kerosene tins as well as Japanese cakes called manju, 
a steam bun full of sweet beans, which were carried on trays. The men would go out early in the morning carrying the trays of tofu on a bamboo rod with the drums hanging off. They would call out in Japanese ... They carried steam buns on wooden trays on their shoulder. You had to order. They had big pinewood trays with rows of steam buns. ${ }^{7}$

Islanders, introduced to these new foods either by family connection or in the family-like contexts of the boats, ${ }^{8}$ began to plant zinza ('ginger') and tigras ('lemon grass') in their own gardens on the outer islands and incorporate them along with seasonings such as pas, a local variety of basil, into their traditional dishes of turtle and dugong, yam and sweet potato, which were slowcooked in sand ovens.

The main foodstuff imported for the Asian crews was their dietary staple, rice, although this did not become common on the outer islands until about 1912. In 1881, a single ship from Hong Kong brought 200 bags of rice to Thursday Island ${ }^{9}$ and Kyuuhara quotes from a letter by a Japanese indent, Sannosuke Masuda, who arrived in 1883: 'We loaded Chinese rice of sixty pyo [1 pyo is equal to $64 \mathrm{~kg}$ ] as our food which we carried from Hongkong', as well as other cooking utensils, which they transported to the pearling station on Muralag (Prince of Wales Island). ${ }^{10}$ By 1885, the Government Resident informed the Colonial Secretary: 'As regards rice, I can only say that for every one, whether European or Asiatic, who lives in the Tropics, rice is a necessity of life.' ${ }^{11}$ The European and Pacific Islander staple starch was flour, not rice, but, by 1917, the Church of England mission was providing its theological students and lay workers with an allowance of rice, as well as flour, tea, sugar, baking powder and jam. ${ }^{12}$ Flour and rice have today become staples of the 'traditional' Torres Strait diet, rice being served at almost every midday and evening meal and invariably at feasts. A local variant is sabi rais, rice cooked in coconut milk and often flavoured with saffron or turmeric. ${ }^{13}$

More than half the 76 dishes in Edwards' traditional Torres Strait Islander cookbook are Asian-inspired. ${ }^{14}$ Nasi Rice and Company Rice are among the recipes and the Islanders have also adopted vermicelli, which they call 'Chinese Macaroni', and the tamarind. ${ }^{15}$ Vermicelli is the basis for simur siken, a Malay dish locally called 'Chinese Chicken' (chicken, Chinese noodles, mushrooms, bamboo shoots and soy sauce). ${ }^{16}$ A local dish called 'Choppy', probably Malay, consists of strips of beef and shredded cabbage tossed and lightly fried. The Malays also introduced various condiments and spices, such as curry powder, which is now used in traditional Torres Strait Islander sabisabi dishes (meat, fish or root vegetables cooked in coconut cream). Any meat, dugong, turtle, fish or vegetable dish may be curried. Jamel Shibasaki, born on Thursday Island in 1927 of Japanese-Malay-Torres Strait Islander descent, recalled that 
our meals consisted of rice, fish, meat, chickens that we raised, which was made into curries, 'simured' which was chicken, Chinese noodles, mushrooms, bamboo shoots and soya sauce. We were able to get Japanese soy sauce in those days ... We also made a lot of sambal with prawn paste and chillies. We liked our spicy foods. Other things were cucumber cooked in coconut milk and other spices. We used to prepare deer meat, sliced thin, marinated in curry powder, sugar and salt and lemon juice. Let it stand over night, then sun dry them. They can be eaten as is, roasted over coals or cooked in peanut oil with fresh ginger and garlic. The salted fish can also be cooked this way. We used tamarinds soaked in hot water, then squeezed and used for cooking. Tamarinds coated with a mixture of sugar and salt make a nice sweet. ${ }^{17}$

Rice, ginger, garlic, curry powder and soy sauce are known by their English names; but blasan ('blachan') and sambal ('sambal'), from Malay, demonstrate their Asian provenance (as they do in English). According to one writer, sambals have been

changed and modified to suit the available ingredients, but are basically a hot spicy dish built on a foundation of onion, garlic, ginger and bird's eye chillies, plus a choice of some savoury pieces of meat, fowl or fish. The Island influence can be seen in some of the ingredients: pearl shell meat and mud clams for instance. ${ }^{18}$

The author notes that some Islanders now use the two terms interchangeably, a sure proof of linguistic nativisation, and gives 11 different Torres Strait recipes for blachans and sambals.

Asian crewmen also introduced new methods of food preparation. Islanders adopted the Chinese method of chopping up fowl for the pot ${ }^{19}$ and, according to Ohshima,

the method of cooking rice was adopted from the Japanese fishermen. Islanders use the absorption method, the Japanese way. They use their index finger to measure the amount of water. The rice that is eaten in Torres Strait is prepared in a way similar to the Japanese style and different from Southeast Asia, which is dry. ${ }^{20}$

Japanese skippers also showed their Islander crews how to salt-cure fish and how to make namas (from the Japanese namasu, but now seen as an Islander dish) by thinly slicing raw fish and marinating it in vinegar, ginger, garlic and chilli. Islanders further elaborated namas by adding a small quantity of coconut milk before serving and called it sabi namas. ${ }^{21} \mathrm{~A}$ variant of namas, called namas kenilau, came via the Philippines 22 and the Filipinos also introduced dinagwan ('blood pig', the Pacific Islander pwakablad). 
Along with their foodstuffs, Asian immigrants imported various cooking implements and eating utensils. Excavating the remains of a 19th-century pearling station near Heath Point on Muralag (Prince of Wales Island), Kyuuhara and his colleagues found

a big iron cooking pot for rice $(93 \mathrm{~cm}$ in inner diameter and $70 \mathrm{~cm}$ in depth) lacking its lid, concealing itself in luxuriantly growing grass. This iron cooking pot would have been brought all the way from Yokohama with 37 emigrants in $1883 .{ }^{23}$

Chinese containers and crockery were also imported, sold in the shops of Thursday Island and taken to the outer islands: Gina Whap Baira informs me that an abandoned Chinese or Malay camp was discovered some time ago close to Wagadagam on Mabuiag, with Chinese crockery found in the scrub above the shore. ${ }^{24}$ Islanders initially perceived the decorated crockery, mainly plates, bowls and mugs, as luxury items and women would place them in their homes for show as well as utility. Today's crockery dishes and enamel cups, used for everyday meals and at feasts on the islands, are almost always imports from China.

\section{Lexical borrowing}

The three Torres Strait Islander languages and Torres Strait English have all been enriched by the introduction of vocabulary from Chinese, Japanese, Malay and Tagalog. The largest components of this borrowing are family, personal and boat names, but a small number of place names, address terms, food terms and a few Japanese commands or expressions have also been borrowed. That they have become nativised is shown by their altered form ('Assan' for 'Hassan', 'Ilario' for 'Hilario', 'Zosapina' or 'Pina' for 'Josephina', 'Rapaila' for 'Raphaela', 'blasan' for 'blachan') and the extension of their contexts of use. The following are some well-known contemporary Torres Strait surnames of Asian provenance. Given the degree of intermarriage and adoption that has occurred since World War II, however, Asian names are now not necessarily restricted to individuals of Asian descent.

\section{Surnames}

Malay Adams (from Adam Musinip), Ah Boo, Ahmat (eight different families so named), Ahwang, Assan, Barba, Binawel, Bindoraho, Bingarage, Binhamed, Binhoosen, Binjuda, Binsiar, Bintahel, Bowie, Dewis, Doolah, Drummond, Jia, Kaprisi, Kitchell, Loban, Malay, Salaam, Seden, Solomon, Tatipata, Titasey. 


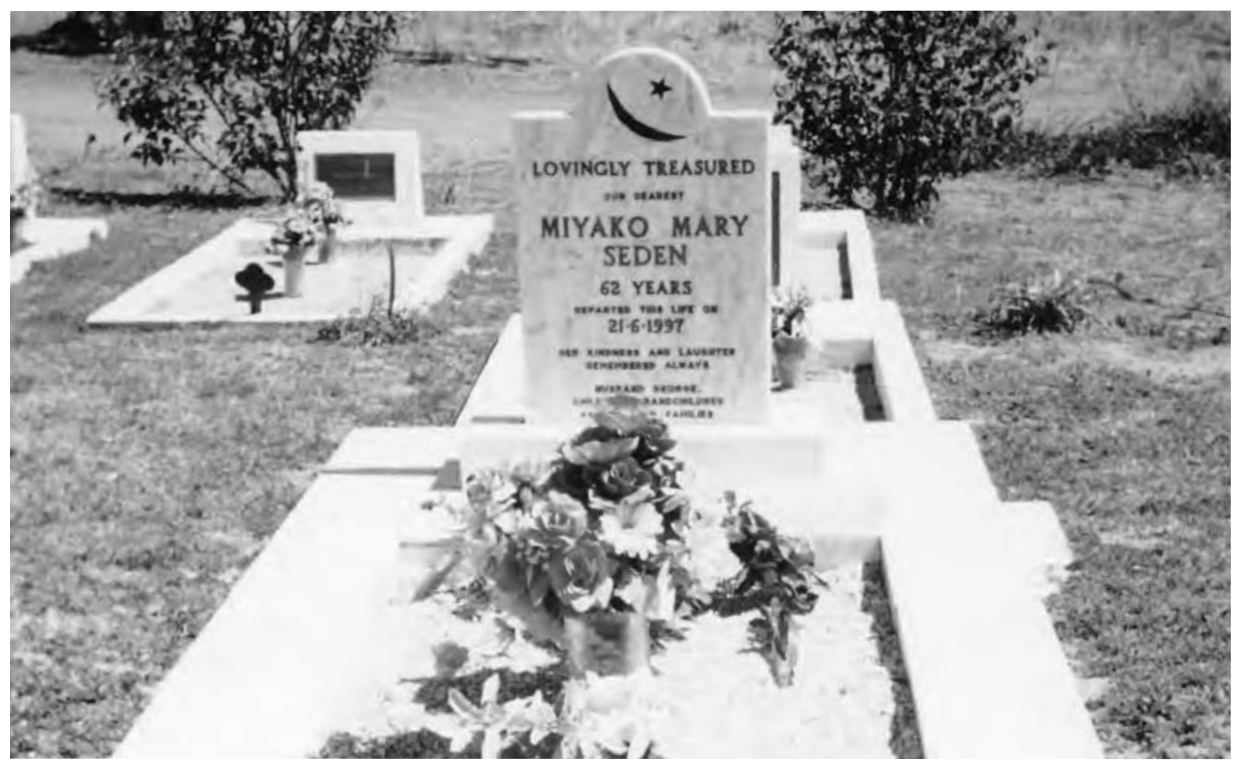

Grave of Miyako Mary Seden, Thursday Island Cemetery, 1997. Courtesy of Guy Ramsay.

Filipino Alcala, Assacruz, Blanco, Bullio, Canendo, Canuto, Carabello, Cloudy (Claudio), Conanan, Delacruz, Dorante, Elarde, Fabian, Francis, Galora, Garcia, Garr, Guivarra, Irlandes, Jose, Kanak, Lanzarote, Lasica, Lohada, Lopez, Macbire, Manantan, Mayor, Pelayo, Rapol, Raymond (from Ramon Roas), Remedio, Sabatino, Santos, Sim.

Sri Lankan Mendis, Mowlis, Saranealis.

Japanese Fujii, Fukumura, Ikeda, Hirakawa, Nakata, Shibasaki, Takai, Tanaka, Yamashita.

Chinese Ahfat, Ahloy, Asange, Chinsoon, Laifoo, Seekee, Sing.

\section{Personal names}

Personal names form the second-largest group of lexical borrowings. The following is indicative, but by no means a complete list, of common contemporary Torres Strait Islander personal names of Asian origin.

Malay Abdul, Abdullah, Ali, Hassan (Assan), Hismyal (Hismile), Ibrahim, Karim, Jamal, Mohammad (Mohamet, Mohamat, Muhammad), Omar, Rahman, Wahap, Wahid; Hagiga, Napsia, Noranee, Patimah, Raimah, Rasma, Saia, Salemah, Zillah. 
Filipino Antonio, Aurelio, Basil (from Basilio), Casimero, Celestino (Tinoi), Cornelio, Faustino, Francisco, Hislo, Ilario (from Hilario), Lucio, Pedro, Seriaco, Seto (from Inisceto), Stanislaus; Ambrosia, Camilla, Evelina, Francesca, Isabella (Bella), Johanna, Josephina (Pina), Laura, Lucia, Luneta, Magdalena, Marcellina, Maria, Monica, Raphaela, Scholastica, Teresa, Thecla, Veronica, Victorina. ${ }^{25}$

Japanese Hideo, Iwazu, Kazu, Kenji, Kyozo, Kyu (Kew); Ayako, Harumi, Kazuko, Misako, Miyako, Sadako, Utako, Yoshiko. ${ }^{26}$

\section{Boat names}

A subsection of personal names consists of boat names of Asian provenance, all the Filipino-named being owned by Heriberto Zarcal of Thursday Island (see Rey Ileto's Chapter Five, this volume):

Filipino Aguinaldo, Esperanza, Fortales, Justicia, Kalayaan, Kapayapaan, Katipunan, Kavite, Lacandola, Llanera, Magdalo, Manila, Maria Eusebia, Natividad, Santa Cruz, Sikatuna, Tagalog, Templanza. ${ }^{27}$

Japanese Banzai, ${ }^{28}$ Enodi, Mikado.

\section{Reference and address terms}

There is a small number of reference and address terms:

Malay bibi 'sister, auntie': Ellie Loban Gaffney, for example, the daughter of a Malay father and European-Islander mother, is generally referred to as Bibi Ellie, although her husband, a European, is called 'Uncle Tony'.

patsi 'uncle' nene 'grandmother' dato 'grandfather'

Japanese kuksang 'cook' 29 nisang 'skipper' 30

Tagalog tiyo 'uncle'

Chinese pana 'friend' 31

This list includes at least two Japanese nicknames, bestowed on Islanders by their Japanese boat captains:

Kosi (given to Timothy Tamwoy, born 1919). According to a nephew, he was given the name 'Kosaka' by a Japanese man, and called 'Kosi' as a pun on 'Koztrabel' (trouble-maker).

Sobo (given to Tom Lowah, born 1914). According to Lowah, on his first voyage out on the boats at the age of 14 , 'The three other Japs addressed me as "Sobo" [little one] and some address me so to this day. 32 


\section{Place names}

As expected, few place names in Torres Strait are of Asian origin and no traditional locations were renamed. I know of only two place names of Asian origin:

Yokohama the Asian quarter on Thursday Island.

Enodi a place at St Paul's community on Mua (Banks Island) belonging to the Morrison family. The family says that it means 'sunset' in Japanese and was probably named for the Burns Philp boat on which a member of the Morrison family crewed under a Japanese captain. ${ }^{33}$

\section{Other borrowings}

The following words of Asian-language origin are also found in the Indigenous languages:

Malay blasan 'blachan'

makan 'to eat'

sambal 'sambal'

samasama 'equal'

Japanese itayo 'it hurts' (from itai 'painful' + yo 'I tell you')

Kura Kura 'Japanese (language)' (from kura! 'Watch it!', a

disapproving phrase in Japanese)

namas 'raw fish' (from namasu 'marinated raw fish')

oisanyo 'hoist 'im up' (from hoist + san 'Mister' + yo 'I tell you')

Tagalog dinagwan 'pig blood'

tuba 'fermented coconut milk'

namas kenilau 'Filipino-style rawfish'

Chinese zangsi 'Chinese rice noodles' (from Jiangxi Province)

Lexical borrowing provides an analogue to cultural borrowing and these Asian-language lexical borrowings cluster in three semantic domains: family relationships, food and boat terms. That is, linguistic borrowing was promoted in the context of extended, close personal interaction, such as occurred within the family and on the boats. The majority of family-related words are of Malay origin, but Japanese supplied the bulk of non-family vocabulary, demonstrating a coincidence of linguistic, historical and cultural evidence.

Mortuary Rites: funerals, burials and tombstone unveilings

Torres Strait Islander mortuary rites are sometimes said to have been influenced by South-East Asian customs, although there is no direct historical evidence of this. At Malay funerals, however, some of which carried the requirement of feasting, participants were given white envelopes in which to contribute money to help pay for the feast. Others contributed food. These practices, which form 
part of the conduct of contemporary Islander funerals, may be the result of Malay influence.

As for burials, a study of the Thursday Island cemetery found that in all non-European sections offerings of food, toys or items reflecting the character or habits of the deceased had been placed on the graves. This was regardless of ethnic origin or religion and reflects both Muslim and Shinto practice. The Shinto graves often had a bottle of spirits (or Japanese beer) and cigarettes placed on them in the large Japanese memorial in the Thursday Island cemetery. ${ }^{34}$ Tom Lowah, a Torres Strait Islander born in 1914, tells us that, when someone died, the Buddhist Chinese, like the Muslims, put out 'food or drink ... at night in the house for the dead to use, and also on the graves'. ${ }^{35}$ This practice of placing on graves 'cups, empty wine glasses, forks and spoons' and well-loved objects belonging to the deceased was adopted by Torres Strait Islanders. ${ }^{36}$

Less certain is the South-East Asian influence on the secondary mortuary rites, tombstone unveilings (also called tombstone openings), the origins of which are obscure, but which are now integral to ailan pasin. ${ }^{37}$ The tombstone is swathed in fabric and unveiled at least a year after burial during a special Christian service to mark the final departure of the deceased's spirit. FitzpatrickNietschmann characterises the practice as 'not a ceremony of grief but a celebration; a rebirth for the living, as well as for the deceased. Obligations have been fulfilled; the total passage from one world to the next has transpired - for both the living and the dead. ${ }^{38}$ She notes that similar rites occur in many parts of South-East Asia and hypothesises that '[a]ncestors of the Torres Strait Islanders could well have brought parts of a belief system from the west'. However, since Muslim families wrapped the body of the deceased in white cloth before burial and tombstone unveilings are not recorded in Torres Strait until the 1930s, ${ }^{39}$ it is possible that there was some cultural merger between Islander and South-East Asian Muslim rites.

When Nene [grandma] died, because I was 16-17, I had to stand and watch, but I was not allowed to do it. Wipe all the body down and dress her in white calico [cloth] and no clothes, wrapping only. Make like a scarf out of the same material. Had to use all the material. If got 10 yards, had to use it all on the body. Whatever was left was cut up and tied round our wrists. We had to wear it until it fell off by itself. Usually lasted over a hundred days. ${ }^{40}$

Additional evidence comes from the 100-day feast after death celebrated by Muslim Malays on Thursday Island to mark the end of mourning, which sometimes coincides today with Muslim tombstone openings. ${ }^{41}$ 


\section{Music}

There exists a recent body of scholarly work that examines various Asian influences on Torres Strait Islander musical traditions (see Karl Neuenfeldt's Chapter 11, this volume). Traceable Asian influences came directly from the songs of Asian seamen working on luggers in Torres Strait or in the form of artefacts: the phonograph records and musical instruments brought to Thursday Island or purchased with the men's earnings. Attested among the latter are Chinese fiddles, Filipino mandolins, guitars and banjos, Sri Lankan drums and Japanese shamisen and shakuhachi (a bamboo flute). ${ }^{42}$ According to Karl Neuenfeldt, however, direct influences are often difficult to document beyond oral history data, which can still identify a song as having 'Indonesian', 'Timorese' or 'Filipino' influences. Another layer of complexity comes from the fact that some Filipino music is Spanish/Mexican in origin: the Philippines was a Spanish colony until 1898 and the dominant external cultural influence was Spanish; Indonesian music has a discernable Portuguese influence. ${ }^{43}$ During the inter-war years, the Thursday Islanders formed dance bands that played popular music, including Asian influenced or derived songs. Some of these songs remain in the Torres Strait Islander musical repertoire.

\section{Transient Borrowings}

In addition to the borrowings into ailan pasin, scores of other Asian cultural practices and items of material culture (the easiest to track) are attested. Most of them were ephemeral, leaving no enduring imprint: they arose swiftly as a response to otherness and the desire to incorporate it, however briefly, as an elaboration of existing traditional forms and were just as rapidly abandoned. This is not to say that they were unimportant, since they provide the researcher with snapshots that brilliantly evoke the nature and social context of AsianTorres Strait interaction. ${ }^{44}$ This section introduces a few of these transient borrowings, which were for a time incorporated into Torres Strait cultural practice, but which did not become part of ailan pasin: the imbibing of opium and tuba; the wearing of the hachimaki and silk; and various games and sports.

\section{Soporifics and Stimulants}

The Islanders, as far as we know, traditionally used only two mood-altering substances: suguba (tobacco) and gamadha (a kind of kava), both thought to have been introduced from New Guinea. The latter was drunk at the male ceremonial ground before battle. ${ }^{45}$ To these were added opium, introduced by the Chinese, and tuba ('fermented coconut milk', said to be as powerful as gin), introduced by the Filipinos. Under the Protection Acts, the Islanders were 
forbidden any intoxicant but tobacco. The Chinese and some Malays, however, continued to smoke opium in designated opium rooms on Thursday Island until World War II ${ }^{46}$ and made it available to their Islander friends. And tuba was produced and consumed on the outer islands until the 1980s. ${ }^{47}$

Alcohol was prohibited on islands designated as 'Aboriginal reserves' as part of the Queensland Government's system of protection and segregation. European superintendent-teachers, appointed to oversee local affairs, forbade the making of tuba. They disapproved of its intoxicating effects and feared that the method of its manufacture would create a shortage of coconuts on the islands. Islanders, however, continued making tuba in secret and consuming it away from the eyes of the island superintendents. William Walton used to make tuba on (non-reserve) Horn Island in the 1930s. His daughter remembers seeing him take a hanging bunch of coconut blossoms, tying them all together and bending them over an earthenware pot. 'The juice dripped into the pot and, when it was fermented enough, they drank it. Dad used to be very happy some evenings.' Her mother used to ask him to keep some of it for her to ferment further to make vinegar. ${ }^{48}$

The writer and journalist, Colin Simpson, visited the islands in 1933 and described the local method of making tuba.

Tuba is made by cutting off the bearing stem of the coconut palm, catching the sap that drips out of the tree and putting it aside to ferment. On the first day the liquid is merely yeast; in about 24 hours it is like light beer in strength ... It has a rather refreshing taste under its sour, sweet smell, and a few minutes after it is taken the stomach begins to glow with a pleasant warmth. But week-old tuba is more than warming, and it goes right to the head. ${ }^{49}$

He also noted a local innovation, evidence of the 'nativisation' of the process, in the addition of a piece of mangrove bark to make a more potent variety.

\section{Adornments, Games and Sports}

Asian adornments, along with various games and sports, were at times co-opted into island ritual. According to Ohshima, the Islanders adopted the Japanese custom of wearing hachimaki when working, although the word itself was not borrowed. ${ }^{50}$ Yuriko Nagata informs me that the cloth is thin and absorbent, roughly $90 \mathrm{~cm}$ long and $24 \mathrm{~cm}$ wide. It is usually tied around the forehead at the front and, in Japan, it is a symbol of determination. Some older Islander men, who crewed with Japanese skippers, still wear it when they embark on a strenuous task and a variant is sometimes worn by male dancers. 
The beauty and lustre of imported Chinese silk was a revelation to Torres Strait Islanders. They were accustomed to clothes made of heavy cotton, coarse serge and even canvas. The Chinese and Japanese shops on Thursday Island sold silk, but Islanders could not afford to buy this luxury item until after World War II. For a time, it became the custom at eastern island weddings 'before the evening dance begins, for the groom's sisters-in-law to wrap both husband and wife with a very expensive material, mainly silk, ${ }^{, 51}$

In May 1898, the anthropologist, Haddon, then living on Murray Island, attended a segur ('play') in one of the villages. ${ }^{52} \mathrm{He}$ described how one group of young women, singing Japanese and other songs, 'had covered their faces with white, and had painted a dab of red pigment on each cheek, perhaps in imitation of the Japanese women of the settlement in Thursday Island which goes by the name of "Yokohama"'. Few of the women who painted their faces would have seen the Japanese karayuki-san of Thursday Island and their men would be unlikely to have been their clients. As a striking visual phenomenon, however, it would have resonated with a people accustomed to painting their faces for war and dance.

When human geographer George Ohshima visited Masig (Yorke Island) in the 1970s, he was invited to attend a sports festival. To honour the visit, the Islanders included various games they had been taught by Japanese divers during their short stays on shore more than 40 years before, when they participated in Islander feasts and celebrations. The games included a spoon race, a local variant of a dunking race and a tug of war. ${ }^{53}$ Islanders also incorporated into their leisure activities some of the Asian games of chance they had learned on the boats and through frequenting the gambling rooms of Malaytown on Thursday Island. Some of the games attested are mahjong, fantan, che $f a$ and dominoes.

\section{Concluding Discussion}

Contact with outsiders introduced the Islanders of Torres Strait to European food and tobacco, as well as to the varied garden produce planted by Pacific Islanders. Under the tutelage of the Filipinos, they manufactured and drank tuba 'coconut liquor'; the Indonesians brought rice and blachan; the Japanese rice, namas and soy sauce. Islanders incorporated the more sophisticated gardening practices of the newcomers and copied and elaborated their clothing, utensils, recipes, dances, songs and crafts. New patterns of living, speaking and thinking arose as the physical character of the islands altered subtly.

Exposure to outside cultural elements is, it almost goes without saying, a necessary condition for borrowing to occur, but it is not sufficient for borrowing 
to endure and become integrated into a given cultural system. The duration of contact and its level of intimacy emerge as the two factors necessary for nativisation of cultural borrowing. The most enduring Asian influences on Torres Strait ailan pasin originated within the domestic sphere. They emerged from the daily activities of the blended families of Asian-Indigenous heritage or the 'family-like' environment of the boats, principally the reciprocal sharing of food and recreational activities, and are summations of myriad cultural accommodations and interpersonal negotiations. Of more than 1,000 preWorld War II Torres Strait families, slightly fewer than 15 per cent were headed by Asian immigrants and almost all of these lived on the islands of the Prince of Wales Group: 70 were headed by 'Malays' (mostly from present-day Indonesia, Singapore and Malaysia), 53 by Filipinos, seven by Japanese, six by Chinese, and five by Sri Lankans. These do not include 'irregular' unions, which, despite the stability and longevity of many of them, were not officially recognised. ${ }^{54}$ In some families, there was explicit teaching of Asian culture and values; in others, the teaching was indirect, gained through childhood and adolescent exposure to community practices.

We can observe three main historical phases in the adoption of Asian cultural elements by Torres Strait Islanders. The original 'carriers' of Asian custom were the male immigrants, who formed discrete but cooperative communities of 'countrymen' on Thursday and Horn Islands and were free to follow their own customs. Their contact with the Islanders was virtually unrestricted until the latter became subject to the Protection Acts. Many early immigrants married local women, who 'adopted the culture of their husbands' and whose children, brought up in 'families practising a predominantly Asian culture', intermarried. ${ }^{55}$ Between the wars, when Asian contacts with the outer islands were stringently regulated and Asian-Indigenous marriages largely prohibited, Asian custom was transmitted primarily through the existing mixeddescent or 'Coloured' population centred on Thursday Island. During this period, however, despite official disapproval, enduring friendships continued to be formed between Asians and Islanders. Japanese boat crews visited Masig during the inter-war years, for example, where 'they taught us how to dive, mend nets, cook rice, prepare namasu'. ${ }^{56}$ The two groups also exchanged songs. After World War II, Asian influence was filtered through families, which, while celebrating their Asian heritage, had lost almost all personal connection with their communities of origin and in which the Asian connection was muted by mainstream custom and religion. All Torres Strait Islanders today, however, regardless of their ethnic heritage, are the beneficiaries of this unique confluence of Asian and Indigenous traditions. 


\section{Acknowledgements}

I am indebted to Yuriko Nagata for her translation of Ohshima's research findings and to Yuriko Nagata, Karl Neuenfeldt and Guy Ramsay for information and comments. My deepest thanks also to Imam Uzair Akbar, Georgina Whap Baira, Maria Johnson Gebadi, Monica Walton Gould, Minoru Hokari, Kemuel Kiwat, Ted Loban (now deceased), Tom Lowah, Amira Mendis, Rod Mitchell, Gwen Clark Moloney (now deceased), Angela Ware Morrison, Eva Salam Peacock, Jianna Seden Richardson, Joan Staples, Titom Tamwoy, Ada Ware Tillett, Celestino (Tinoi) Williams and Ken O'Shea (Woodhead).

\section{Footnotes}

1 This chapter is based on a paper, 'Asian influences on "traditional” Torres Strait Islander custom', presented at the conference, 'Transforming Cultures/Shifting Boundaries: Asian Diasporas and Identities in Australia and Beyond', University of Queensland, 30 November, 2001.

2 Published research on Asian cultural influence in Torres Strait has focused on the music of the region, for example: Hayward, P. and J. Konishi. 2001. 'Mokuyo-to no ongaku: music and the Japanese community in the Torres Strait (1890-1941).' Perfect Beat, Vol. 5, No. 3. pp. 46-65. And Neuenfeldt, K. Chapter 11, this volume. The research by G. Ohshima and his team, some of it published as Ohshima, G. 1977, 'Yooku-too yuuki [Yorke Island travel diary],' Chiri, Vol. 22, No. 9, pp. 56-62, and under Ohshima's editorship as Toresu Kaikyo no hitobito: people of the Torres Strait, Tokyo, 1983, Kokon Shoin, is in Japanese, although preliminary reports in English are held by the Australian Institute of Aboriginal and Torres Strait Islander Studies (hereafter AIATSIS) in Canberra. Kyuuhara, S., 'Remains of Japanese on Torres Strait islands', March 1977, is a typescript held in the John Oxley Library (hereafter JOL) as MLC 1791-132; and the 1995 unpublished report compiled by J. Staples and K. O'Shea, 'Thursday Island's Asian heritage: an oral history', in the possession of the author.

3 For a comprehensive discussion of the complex trade routes linking Torres Strait with its neighbours, see Lawrence, D. 1994. 'Customary exchange across Torres Strait.' Memoirs of the Queensland Museum, Vol. 34, No. 2. pp. 241-446.

4 One could argue that cultural distance, which characterised relations at every level between the Islanders and Europeans, might be expected to impede cultural borrowing, yet we know that Islanders borrowed freely European items of material culture, religious ideology and myriad other influences. In this case, however, other things were not equal. The differential prestige and the authorities' deliberate moulding of post-contact Torres Strait Islander society in accordance with British cultural norms and values encouraged European influence. Moreover, a close examination of European borrowing demonstrates that, at least initially, elements were mediated through European-influenced Pacific Islanders. Direct observation of Europeans by Islanders was rare and circumscribed, the two groups being separated for more than a century by ideological, socioeconomic, administrative, legislative and political barriers.

5 Maria Johnson Gebadi, pers. comm., August 2000.

6 Nagata, Y. 1996. Unwanted Aliens: Japanese internment in Australia. St Lucia: University of Queensland Press. p. 20.

7 Gwen Moloney, pers. comm., January 2001.

8 I owe this insight to Minoru Hokari, pers. comm., November 2001.

9 Copy of letter from 'E. L. Brown, Thursday Island to Colonial Secretary, 22 June 1881', attached to report from 'Inspector J. A. Peterson, Thursday Island, to Colonial Secretary on complaints against Mr Chester, 28 July 1881.' COL/A321/3879, Queensland State Archives (hereafter QSA). 
10 Kyuuhara, S., 'Remains of Japanese on Torres Strait islands', p. 12.

11 'Report from John Douglas, Thursday Island, to Colonial Secretary, 1 July 1886.' COL/A457/1583, QSA.

12 'Bishop of Carpentaria to Rev Jones, 14 February 1917', Bishop's correspondence, OM.AV 61/2; and to Rev. Cole, 13 December 1917, Bishop's correspondence, OM.AV 61/3, JOL.

13 Ted Loban, pers. comm., October 1981.

14 Edwards, R. 1988. Traditional Torres Strait Island Cooking. Kuranda: Rams Skull Press.

15 Ibid. Another name for Chinese Macaroni is Yancy Chicken. For Eva Peacock, 'macaroni' is the generic term and includes the colourless bean thread. Chinese Macaroni, which her mother used to cook, is made with chicken and colourless bean thread, dried mushrooms and ginger. Her mother used to cook it. Eva Peacock, pers. comm., December 2001.

16 The printed leaflet accompanying the Requiem Mass conducted in 1997 for Ella Relo Mills, daughter of Bora Bin Juda from Indonesia and Marijah Dulah Bin Juda from Darnley Island, contains the following: 'Ella was a devoted Catholic and would always cook her famous semur chicken for the Catholic Fetes.' MLC 1791-263, JOL.

17 Staples, J. and K. O'Shea, 'Thursday Island's Asian heritage', pp. 6-7.

18 Edwards, R., Traditional Torres Strait Island Cooking, p. 57.

19 According to Edwards, R., ibid., p. 37, Islanders use the Chinese method of chopping up fowl for the pot.

20 Ohshima, G., Toresu Kaikyo no hitobito, p. 285.

21 Ibid. Edwards, R., Traditional Torres Strait Island Cooking, p. 44.

22 Ibid., p. 45.

23 Kyuuhara, S., 'Remains of Japanese on Torres Strait islands', p. 12.

24 Georgina Whap Baira, pers. comm., November 2001.

25 During the period of Spanish colonial rule, Filipinos were given Spanish names at registration or baptism.

26 Some Japanese-born immigrants anglicised their Japanese names, e.g., Tomitaro (Tommy) Fujii. Their Torres Strait-born children tended to be given two names, one Japanese and one English.

27 Pugh, T. P. 1904. Pugh's Almanac. Brisbane. Facing p. 770. According to Ileto, the following boats in Zarcal's fleet allude to Philippine history, nationalism, the revolution and his own past: Santa Cruz (Zarcal's birthplace), Kavite (the heartland of the revolution), Sikatuna and Lacandola (preSpanish chiefs), Magdalo (Aguinaldo's Katipunan name), Kalayaan (Liberty), Kapayapaan (Peace), Justicia (Justice), Esperanza (Hope) and Filipino.

28 Banzai, meaning 'long live', was the name of the cutter (single-masted sailboat) based at St Paul's Anglican Mission from c.1909, which used to travel between the mission and Thursday Island with mail, produce, stores, etc. Rev. W. H. M. MacFarlane, AIATSIS MS 2616/1/3, Book 2. Jones, E. 1921. Florence Buchanan: the little Deaconess of the South Seas. Sydney: Australian Board of Missions. p. 51.

29 From English 'cook' plus Japanese san, 'Mister'.

30 According to Tom Lowah, pers. comm., 1981, crews called their Japanese skippers 'nisang' as a title of respect. The word in Japanese is niisan [ni:sã] 'older brother', says Yuriko Nagata, pers. comm., May 2003.

31 Kemuel Kiwat, pers. comm., July 2000, told me that the Japanese men on the boats used to say: 'Hey, pana!' The Chinese word is pangga 'friend'.

32 Lowah, T. 1988. Eded Mer: my life. Kuranda: Rams Skull Press. p. 43. Sobo means 'small man' in English, says Yuriko Nagata.

33 According to Yuriko Nagata, the word is probably hinode, hi meaning 'the sun', de 'to come out' and no a connective meaning something like 'of'. 'Sunset' would be hinoiri.

34 Ayscough, H. 1914. Priests in Carpentaria. London: Lincoln and Southwell Branch of the Carpentarian Association. p. 18. 
35 Lowah, T., Eded Mer, p. 65.

36 Burchill, E. 1972. Thursday Island Nurse. Adelaide: Rigby. p. 42. This was also the view of Ken O'Shea, pers. comm., July 1992, whose mother was raised partly in the Muslim family of Assan and Lass Ah Boo. The plates, ashtrays, cups and glasses on the graves are sometimes left there after visits by the family, who take food for themselves and the deceased as one might do 'for a family member in hospital'.

37 See Fitzpatrick-Nietschmann, J. M. 1981. 'Tombstone openings: cultural change and death ceremonies in Torres Strait, Australia.' Kabar Seberang, Vol. 8, No. 9. pp. 115. Lui, A. L. 1988. 'The Last Farewell: maintaining customary practice in Torres Strait Islander society.' Grad. Dip. of Material Anthropology thesis, James Cook University of North Queensland.

38 Fitzpatrick-Nietschmann, J. M., 'Tombstone openings', p. 13.

39 Sharp, N. 1993. Stars of Tagai: the Torres Strait Islanders. Canberra: Aboriginal Studies Press. p. 116.

40 Seriba Shibasaki quoted in Staples, J. and K. O'Shea, 'Thursday Island's Asian heritage', pp. $11-12$.

41 This was the view expressed by Jamel Shibasaki in ibid, p. 13. Imam Uzair Akbar from Brisbane explains that the Muslim religion does not teach that a feast should be held 100 days after death, but suggests the Thursday Island custom may be a syncretic practice influenced by pre-Islamic cultural traditions in the Malay Archipelago and brought by the immigrants into Torres Strait. Seriba Shibasaki also comments 'that the Malay Muslim practice is different in many ways from that of the Arabian' (p. 11). In her family, 'the Malay rites include a tea three days after death, and feasts at 7, 40 and 100 days'. Jianna Seden Richardson, pers. comm., June 2003, says that in her family burials were very low-key affairs, with just the family and friends present. At the burial, the relatives drank tea, then again on the third and seventh days; on the 40th day, the family had chicken meat. There was a feast on the 100th day after burial to end the period of mourning, but it was not a celebration and, again, only the family and friends were invited. Hayward, P. and J. Konishi, 'Mokuyo-to no ongaku', p. 55.

43 Karl Neuenfeldt, pers. comm., November 2001 and May 2003.

44 As Hayward, P. and J. Konishi, 'Mokuyo-to no ongaku', p. 59, point out, judgments about the significance of cultural phenomena based solely on their continuing influence are historically biased in privileging 'the [incidental] present'.

45 Rod Mitchell, pers. comm., 1998.

46 Staples J. and K. O'Shea, 'Thursday Island's Asian heritage', p. 9.

47 Kemuel Kiwat, pers. comm., August 1982.

48 Monica Walton Gould, pers. comm., March 2003.

49 Simpson, C. 1933. 'Island "hooch": no liquor of the white man.' The Sun, 27 November, 1933.

50 Ohshima, G., Toresu Kaikyo no hitobito, p. 285.

51 Autobiography by Catherine Martha Cook, dated 1989, typed manuscript in possession of the author.

52 Haddon, A. C. 1901. Head hunters: black, white and brown. London: Methuen. pp. 36-7.

53 Ohshima, G., 'Yooku-too yuuki', p. 60.

54 Some of the children of these unions claim that non-Christians were not permitted to marry legally on Thursday Island.

55 Staples, J. and K. O'Shea, 'Thursday Island's Asian heritage', p. 1.

56 Ohshima, G., Toresu Kaikyo no hitobito, p. 79. 


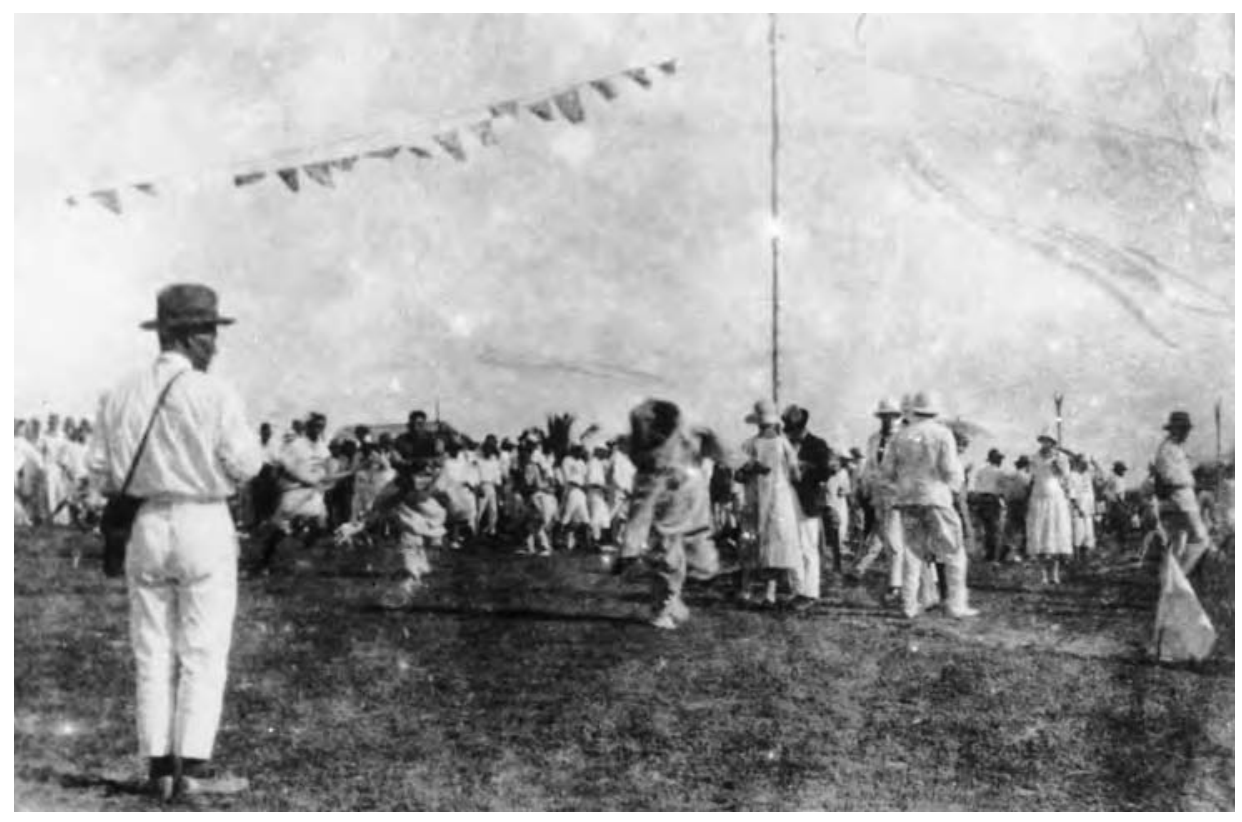

Thursday Island festivities, 1925.

Courtesy of John Oxley Library, Brisbane (Item No. 185118). 
This text is taken from Navigating Boundaries: The Asian diaspora in Torres Strait, edited by Anna Shnukal, Guy Ramsay and Yuriko Nagata, published 2017 by ANU eView, The Australian National University, Canberra, Australia.

dx.doi.org/10.22459/NB.11.2017.10 